REGARDS

SUR L'ECONOMIE ALLEMAND

BULLETIN ECONOMIQUE DU CIRA
Regards sur l'économie allemande

Bulletin économique du CIRAC

$65 \mid 2004$

Varia

\title{
Distribution : le « modèle » ALDI
}

Isabelle Bourgeois

\section{OpenEdition}

\section{Journals}

Édition électronique

URL : http://journals.openedition.org/rea/3952

DOI : 10.4000/rea.3952

ISBN : 978-2-8218-0826-3

ISSN : 1965-0787

Éditeur

CIRAC

Édition imprimée

Date de publication : 1 mars 2004

Pagination : 38

ISSN : 1156-8992

Référence électronique

Isabelle Bourgeois, « Distribution : le « modèle » ALDI », Regards sur l'économie allemande [En ligne], 65 | mars 2004, mis en ligne le 29 octobre 2009, consulté le 15 septembre 2020. URL : http:// journals.openedition.org/rea/3952

Ce document a été généré automatiquement le 15 septembre 2020.

(C) CIRAC 


\title{
Distribution : le « modèle » ALDI
}

\author{
Isabelle Bourgeois
}

1 En Allemagne plus qu'en France, le commerce alimentaire de détail est en recul face au hard discount. Les Lidl, Tesco et, surtout ALDI, se taillent une part de marché (plus de $37 \%$ ) en forte progression. Ils ont profondément modifié le comportement d'achat des Allemands. Ce n'est pas tant le facteur prix qui les attire, que « la gamme réduite de produits, des gondoles simplifiées et le gain de temps ", explique une récente étude réalisée par le cabinet McKinsey, qui conseille au commerce de détail de s'inspirer des méthodes du hard discount. ALDI est de loin le leader en Allemagne, avec un CA annuel de quelque 33 milliards $€$; c'est un sixième du CA de Wal-Mart. Dans un portrait du groupe familial, qui vient d'être publié aux Editions Campus (Dieter Brandes, Die 11 Geheimnisse des ALDI-Erfolgs), son ancien PDG livre les secrets d'une success story qui avait débuté en 1948 à Essen, dans la Ruhr. Au sortir de la guerre, la gamme de produits disponibles et abordables était alors forcément réduite. A l'époque, la nécessité faisait loi. L'austérité est devenue culte: ALDI est aujourd'hui un lieu 'branché' pour cette bourgeoisie frileuse qui compose ce que les sociologues d'outre-Rhin appellent le 'nouveau centre'. (IB)

\section{INDEX}

Mots-clés : distribution, consommation, Aldi, commerce, commerce de détail, alimentation, magasin 